Chirurgia (2021) 116: 271-283

No. 3, May-June

Copyright@ Celsius

http://dx.doi.org/10.21614/chirurgia.116.3.271

\title{
Laparoscopic Total Extraperitoneal Repair and Open Prolene Hernia System for Inguinal Hernia Repair Have Similar Outcomes: A Retrospective Study
}

\author{
Sergio Susmalliann ${ }^{1,2}$, Royi Barnea ${ }^{2,3}$, Oleg Ponomarenko ${ }^{4}$ \\ 'Department of General Surgery, Assuta Medical Center, Tel Aviv, Israel \\ ${ }^{2}$ Faculty of Medicine, Ben Gurion University of the Negev, Beer Sheva, Israel \\ ${ }^{3}$ Assuta Health Services Research Institute, Assuta Medical Center, Tel-Aviv, Israel \\ ${ }^{4}$ Department of General Surgery, Barzilai University Medical Center, The Sheila and Eric Samson Surgical Hospital, Ashkelon, Israel
}

*Corresponding author:

Sergio Susmallian M.D.

Department of Surgery

Assuta Medical Center

20 Habarzel Street

Tel Aviv, 69710 Israel

Tel: $+972-52-4637743$

Fax: $+972-3-7644313$

E-mail: sergio9@bezeqint.net

Received: 06.03.2021

Accepted: 22.05 .2021

\section{Rezumat}

Rezultate similare ale procedeului total extraperitoneal și ale alloplastiei cu prolene pe cale deschisă în repararea herniilor inghinale: un studiu retrospectiv

Obiectiv: Compararea rezultatelor curei chirurgicale a herniilor inghinale prin procedeu laparoscopic total extraperitoneal (LTEPR) cu cele prin abord deschis, alloplastic (OPHSR), în ceea ce priveşte complicațiile, durerea postoperatorie şi calitatea vieții.

Context:Cura herniei inghinale este una dintre cele mai frecvente intervenții chirurgicale practicate în chirurgia generală. În ciuda dezvoltării tehnologice şi a progreselor ştiințifice, încă nu a fost posibilă definirea standardului de aur pentru repararea herniilor inghinale.

Material şi metode:Acesta este un studiu observațional efectuat pe un număr de 577 de pacienți consecutivi la care s-a practicat cura chirurgicală a herniei inghinale fie prin LTEPR $(n=293)$, fie prin OPHSR $(\mathrm{n}=284)$. Vârsta medie pentru OPHSR a fost de 62,49 ani şi pentru LTEPR de 55,35 ani. Urmărirea medie de 38,10 luni, timpul operativ mediu pentru OPHSR a fost de 55,58 minute şi pentru LTEPR a fost de 45,46 minute, cu o spitalizare de 1,1 şi respectiv 1,08 .

Rezultate: Fiecare tip de hernie a fost clasificat în conformitate cu criteriile Gilbert / Rutcow-Robbins, La pacienții cu OPHSR, 80,28\% au fost încadrați în clasele 1-3 şi doar $19,72 \%$ în clasele $4-7$. La pacienții cu LTEPR, 52,22\% au fost încadrați în gradele 1-3 şi 
47,78\% au fost clasele 4-7. În grupul LTEPR au existat mai multe complicații, cu 9 cazuri de hemoragie controlată intraoperator, o ruptură a vezicii urinare, însă fără alte complicații viscerale; în grupul OPHSR, au existat mai puține complicații cu diferențe semnificative ( $p=0,014)$. Complicațiile postoperatorii, în principal hematomul şi seromul, au fost cele mai frecvente, fără diferențe statistice. În ceea ce priveşte durerea postoperatorie, în grupul OPHSR, $77,46 \%$ dintre pacienți au raportat durere uşoară sau absența durerii, 21,47\% au raportat dureri moderate şi $1,05 \%$ au raportat dureri severe. În grupul LTEPR, 74,4\% dintre pacienți au raportat dureri uşoare, $25,25 \%$ au raportat dureri moderate şi un singur pacient a raportat dureri severe, fără diferențe semnificative.În ambele grupuri, pacienții au raportat un indice ridicat de satisfacție, iar în grupul LTEPR rezultatele estetice au fost mai bune decât cele ale OPHSR ( $p>0,001)$.

Concluzie: Rezultatele LTEPR sunt similare cu cele ale OPHSR. $\mathrm{Cu}$ toate acestea, LTEPR implică un timp operator mai scurt, mai multe complicații intraoperatorii şi cicatrici mai reduse.

Cuvinte cheie: hernie inghinală, complicații postoperatorii, evaluarea rezultatelor

\begin{abstract}
Objective: To compare the results of Laparoscopic total extraperitoneal inguinal hernia repair (LTEPR) and the open prolene hernia system repair (OPHSR), in terms of complications, postoperative pain and quality of life.

Background: Inguinal hernia repair is one of the most frequent surgeries made by general surgeons. Although, with the technological development and scientific advances even today it is not possible to define which is the gold standard procedure to hernia repair.

Material and Methods: For this observational study, all 577 consecutive patients who underwent hernia repair were included in the study, 293 LTEPR, and 284 OPHSR. The average age for OPHSR was 62.49 years and for LTEPR 55.35 years. The average follow-up of 38.10 months, the mean operative time for OPHSR was 55.58 minutes and for LTEPR was 45.46 minutes, with a hospital stay of 1.1 and 1.08 respectively.

Results: Each type of hernia was classified according to Gilbert/Rutcow-Robbins criteria, resulting in the OPHSR, $80.28 \%$ were assigned to class 1 to 3 and only $19.72 \%$ in class 4 to 7 . In the LTEPR, $52.22 \%$ of the patients are classified in degree 1 to 3 and $47.78 \%$ were class 4 to 7. In the LTEPR group there was more complications with 9 cases of bleeding controlled at the same time, one tear of the bladder, no other visceral complications; in the OPHSR group, there were fewer complications with significant differences $(p=.014)$. The postoperative complications, principally hematoma, and seroma were the most common complication without statistic differences. The postoperative pain was in the OPHSR group, $77.46 \%$ of patients reported suffering from mild or pain-free pain, $21.47 \%$ reported moderate pain, and $1.05 \%$ reported severe pain, in the LTEPR group $74.4 \%$ of patients reported mild pain, $25.25 \%$ reported moderate pain and only one patient reported severe pain, without significant differences. In both groups, the patients reported a high index of satisfaction, and in the LTEPR group scare results were better than OPHSR ( $\mathrm{p}>$.001).

Conclusion: The outcomes of LTEPR are similar to OPHSR. However, LTEPR has shorter operative time, more intraoperative complications and better scar satisfaction.
\end{abstract}

Key words: inguinal hernia, postoperative complications, outcomes assessment 


\section{Introduction}

Abdominal wall hernias are common, with a lifetime risk of $27 \%$ in men and $3 \%$ in women (1).

Inguinal and femoral hernias are the most common affections faced by primary care physicians that require surgical intervention (2).

The most common hernia in both sexes is the indirect inguinal hernia (3). The male-tofemale ratio is 9:1 for inguinal hernias and 1:3 for femoral hernias (3). Inguinal hernia repair is one of the most common operations undertaken in routine surgical practice (4).

Since the introduction of the Bassini method in 1887, more than 70 types of pure tissue repair have been reported in the surgical literature (5). Throughout the years, attention was paid to the recurrences that occur after the use of tissue approximation technique. In the literature it has been reported that they occur in up to $34 \%$ of cases, although, the actual incidence of recurrences is underreported. Therefore, the repair of a hernia with approximation of tissue has practically been abandoned $(6,7,8)$.

The concept of tension-free repair for hernias was introduced by Lichtenstein who explained that the prime etiologic factor behind most herniorrhaphy failures is the suturing together, under tension, of structures that are not normally in apposition (9). The technique of the hernioplasty with the use of mesh was not widely accepted at first, the repairs with mesh have been widespread for years. The usage of mesh increased from $7 \%$ of all operations in 1992 to $51 \%$ in 1996 (10). Currently, groin hernia treatment is not standardized (11) but, today, tension free mesh repair technique is regarded as the gold standard (12).

Based on the Stoppa technique (13), the laparoscopic hernia repair was developed in 1991 (14). The most common laparoscopic techniques for inguinal hernia repair are transabdominal preperitoneal (TAPP) repair and total extraperitoneal (TEP) repair. The use of the laparoscopic technique was progressively increasing based on the advantages of minimally invasive procedures, but since the publication of Neumayer in 2004, where he reports a recurrent incidence in laparoscopic hernia of $10.1 \%$ compared with $4 \%$ for open surgery, the use of laparoscopic repair declines considerably (15). Surgeons remain divided on the best technique for inguinal hernia repair: while more than half never perform laparoscopic inguinal hernia repair (16), today the laparoscopic technique for hernia repair is used in $28 \%$ of cases, of which $25 \%$ is used the TEP approach (11) and is considered the best approach for bilateral inguinal hernia repair (17).

Advantages and disadvantages of TEP are: faster return to usual activities, operation times are longer and it is a higher risk of serious complication rate in respect of visceral (especially bladder) and vascular injuries (18).

In 1999, Gilbert published the use of a bilayer patch device, known as prolene ${ }^{\circledR}$ hernia system (Ethicon; Somerville, NJ, USA) (PHS) to repair an inguinal hernia (19). The unique feature of this polypropylene mesh device is that it has attached the component, its underlay patch provides a pre-peritoneal repair, a connector that has the desirable attributes of a plug and an onlay patch covers the back wall. In the literature, better results have been reported for PHS repair than for Lichtenstein repair $(20,21)$. The advantages of the anterior repair of inguinal hernias are low operative costs, short learning curve, reproducible results at all levels and the possibility of the use of local anesthesia (22).

The objective of this study is to compare the results of laparoscopic total extra-peritoneal repair (LTEPR) with open prolene hernia system repair (OPHSR) retrospectively.

\section{Material and Methods}

In our environment, 10367 (10.41\% of all surgeries) hernias repair are performed in one year, of which 5797 (51.92\%) are inguinal hernia repair, of them $2870(49.51 \%)$ are performed laparoscopically and $2927(50.49 \%)$ are performed using different open repair techniques. 
All consecutive patients who underwent LTEPR of an inguinal hernia from 2003 to 2007 and open OPHSR inguinal hernia repair from 2008 to 2015 , were analyzed. A total of 577 patients were included in the study divided into two groups, the LTEPR group 293 patients and in the OPHSR group 284 patient. The selection of patients for LTEPR was bilateral inguinal hernia or recurrence after open repair, for OPHSR was unilateral inguinal hernia or health condition with preference to regional or local anesthesia. The follow up of all patients was between 18 to 60 months (mean 38.10 months).

\section{Setting}

The patients in the LTEPR group were operated by two surgeons with long experience in laparoscopic hernia repair in a public hospital. The selected patients were those with a bilateral inguinal hernia or a recurrent hernia after open surgery, patients with contraindication for general anesthesia and patients with low midline scar or Pfannenstiel incision were excluded. Medical specialists in surgery with experience in repair using PHS operated patients of the OPHSR group; patients under local anesthesia were excluded.

\section{Operative Technique}

A preoperative prophylactic antibiotic shot of $2^{\text {nd }}$ generation cephalosporin was given to all patients.

For LTEPR, under general anesthesia and supine position, the plane preperitoneal was developed using a kidney-balloon trocar (Covidien-Medtronic, New Haven, CT, USA) using the 45 degrees scope to evaluate the plane. After developing the preperitoneal space, a structural trocar (Covidien-Medtronic, New Haven, CT, USA) was inserted and the space inflated with gas with low pressure. One working 10-millimeter trocar was inserted in the midline as high as possible, it was necessary one more 5-millimeter trocar was inserted under the first one.

An atraumatic dissection of the groin was performed, the regional vessels (Corona Mortis, femoral and epigastric) were recognized, the cord was dissected and the peritoneal edge separated and retracted proximally wherever possible. A broad dissection was performed laterally including the Bogros space and superiorly releasing the peritoneum from the anterior abdominal wall.

To repair the groin, we use a heavyweight polypropylene mesh 15 x 15 centimeters, divided in a piece of $15 \times 5$ centimeter inserted under the cord and fixed with helical tackers (Covidien-Medtronic, New Haven, CT, USA) to the ramus pubis and laterally to the transverse abdominal muscle. The second piece of mesh, $10 \times 15$ centimeter above the cord overlapping the anterior piece and fixing it to

Figure 1. This figure shows a laparoscopic view of an indirect hernia on the right side, the spermatic cord, the pubis and the peritoneal sac separated from the spermatic cord in a wide way, especially its adherence to the spermatic vessel, in addition to ensuring a wide dissection to be able to adapt the mesh

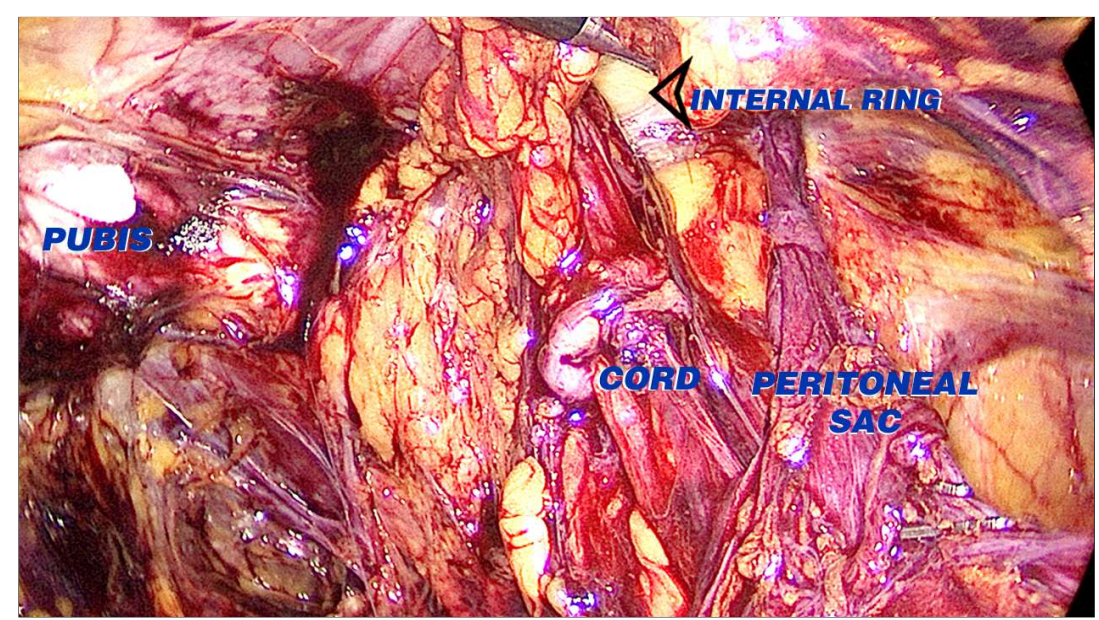


Figure 2. Our technique consists in placing a mesh of 5 centimeters wide by 15 centimeters long behind the spermatic cord, fixing it with absorbable tackers above the symphysis of the pubis and laterally on the abdominal wall, a second anatomical mesh placed anterior and superior to the spermatic cord, attached to the anterior mesh with two tackers similar to the previous one. In this way we build a wall that reinforces the entire inguinal area and does not allow the passage of fatty tissue (hernial lipoma) underneath, thus avoiding recurrence. The wide dissection of the preperitoneal space facilitates the placement of the meshes without folding

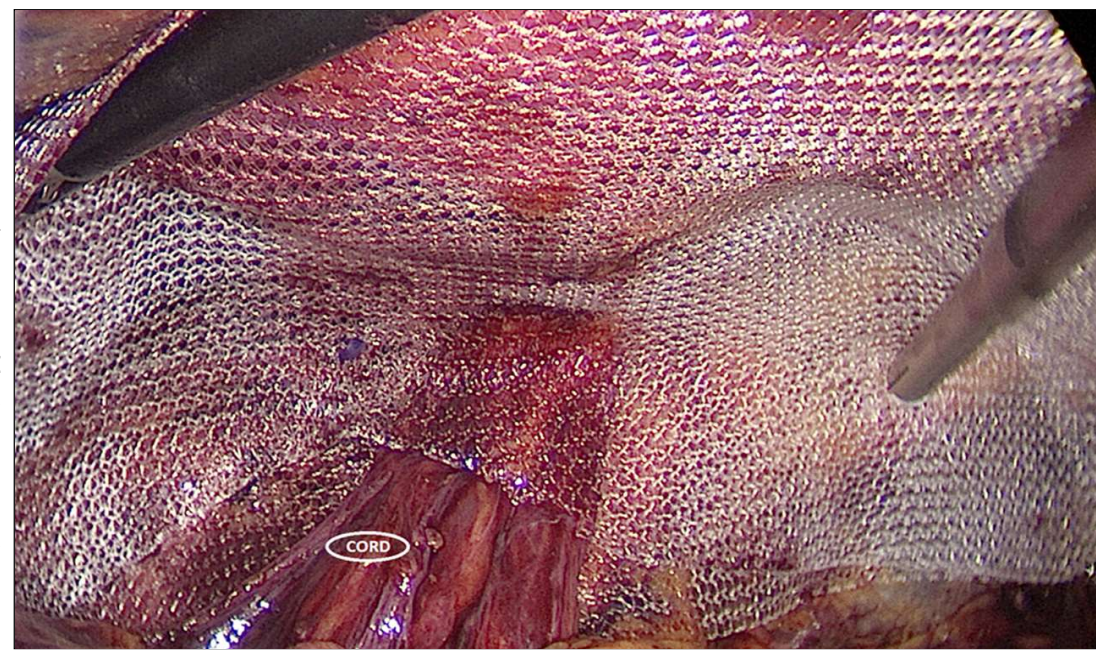

the first mesh inserted. The gas was released and Bupivacaine Hydrochloride $0.5 \%$ was injected through the trocar in the preperitoneal space.

For OPHSR, under regional or general anesthesia, in supine position, the ipsilateral groin was incised transversally, the planes were developed, the cord was isolated and the sac was reduced, the entry to the preperitoneal space was gained by atraumatic dissection, preferable using the finger, through the internal ring in cases of indirect hernias, or medially in direct hernias. The preperitoneal space was developed widely in an atraumatic way. The posterior patch of the PHS was introduced pre-peritoneally and the onlay patch was fixed with continuous polypropylene sutures or separate stitches. Bupivacaine hydrochloride $0.5 \%$ was injected into the tissue around the repair.

\section{Statistical Analysis}

All of the measured variables and derived parameters were tabulated using descriptive statistics. For the categorical variables, the summary tables provided the sample size and absolute and relative frequencies. For the continuous variables, the summary tables provided the sample size, arithmetic mean, standard deviation, median, minimum and maximum values, and $95 \%$ confidence intervals (CI) for the means of the variables.
Analyses were performed using SPSS for Windows version 22.0 (SPSS, Chicago, IL, USA). Differences between two groups were analyzed using the Chi-square test, Fisher's exact test, and t-test as adequate. Results were considered statistically significant at $\mathrm{p}<.05$.

\section{Results}

The mean age for the OPHSR group is 62.49 years (range 18-90 years) and for the LTEPT is 55.35 years (Range 20-90 years), the patients in the OPHER group are older than the LTEPR group with a significant difference $(p<.001)$. In the OPHS group, 89.09 were male and in the LTEPR group $96.25 \%$, with a significant difference $(\mathrm{p}<.001)$. The mean BMI in the OPHR group was $29.34 \mathrm{~kg} / \mathrm{m}^{2}$ and in the LTEPR group was $29.16 \mathrm{~kg} / \mathrm{m}^{2}$, without significant difference.

The American Society of Anesthesiologist (ASA) physical status was determined for both groups demonstrating that the OPHR group has more illness grade compared with the LTEPR with a significant difference $(p<.001)$.

The mean operative time is lower for the LTEPR, 45.46 minutes compared with OPHSR, 55.58 minutes with a significant difference $(p<.001)$. The hospital stay in both groups is similar without a significant difference $(p=.830)$.

Due to the selection of patients for each 
Table 1. Demographic characteristics of both groups

\begin{tabular}{|c|c|c|c|c|}
\hline Characteristics & & OPHSR & LTEPR & $\mathrm{p}$-value \\
\hline Number & 284 & 293 & & \\
\hline Age & 62.49 & 55.35 & $<.001^{*}$ & \\
\hline Range & $18-90$ & $20-90$ & & \\
\hline Gender & $\begin{array}{l}\text { Male } \\
\text { Female }\end{array}$ & $\begin{array}{c}253(89.09 \%) \\
31(10.91 \%)\end{array}$ & $\begin{array}{c}282(96.25 \%) \\
11(3.75 \%)\end{array}$ & $\begin{array}{l}<.001^{*} \\
<.001^{\star}\end{array}$ \\
\hline Mean ( \pm SD) BMI (Kg/m2) & $29.34(4.81)$ & $29.16(6.43)$ & .703 & \\
\hline$\overline{\mathrm{ASA}}$ & $\begin{array}{l}1 \\
2 \\
3\end{array}$ & $\begin{array}{c}84(29.57 \%) \\
156(54.93 \%) \\
44(15.50 \%)\end{array}$ & $\begin{array}{l}191(65.19) \\
81(27.64 \%) \\
21(7.17 \%)\end{array}$ & $<.001^{*}$ \\
\hline Mean $( \pm S D)$ operative time & $55.58(18.471)$ & $45.46(15.907)$ & $<.001^{\star}$ & \\
\hline Mean ( \pm SD) hospital stay & $1.10(0.723)$ & $1.08(1.415)$ & .830 & \\
\hline Bilateral Inguinal Hernia & $26(9.15 \%)$ & $238(81.23 \%)$ & $<.001^{*}$ & \\
\hline Side & $\begin{array}{l}\text { Left } \\
\text { Right }\end{array}$ & $\begin{array}{l}114(40.15 \%) \\
144(50.70 \%)\end{array}$ & $\begin{array}{c}22(7.51 \%) \\
33(11.26 \%)\end{array}$ & $\begin{array}{l}<.001^{*} \\
<.001^{*}\end{array}$ \\
\hline Recurrent hernia & $8(2.82 \%)$ & $41(13.99 \%)$ & $<.001^{*}$ & \\
\hline
\end{tabular}

procedure, there are differences comparing the number of patients with a bilateral hernia or a unilateral hernia in each group $(p<.001)$.

The demographic characteristics of both groups are shown in Table 1.

Each type of hernia was classified according to Gilbert/Rutcow-Robbins criteria, resulting in the OPHSR, $80.28 \%$ were assigned to class 1 to 3 and only $19.72 \%$ in class 4 to 7 .

In the LTEPR, $52.22 \%$ of the patients were classified in degree 1 to 3 and $47.78 \%$ were class 4 to 7 . The LTEPR group includes a greater proportion of patient class 4 to 7 compared with the OPHSR group, the difference is statistically significant, which can be seen in Table 2 .

Simultaneously, other operative procedures were carried out in both groups, in the OPHSR group 8 cases of which 5 umbilical hernia repair, one repair of an epigastric hernia and 2 repairs of hydrocele. In the LTEPR group, 27 cases of combined procedures were carried out, the repair of an umbilical hernia is the most common procedure motivate by the cutting adjacency in the umbilical zone. The differences in combined procedures in significative $(\mathrm{p}<.001)$, as can be seen in Table 3.

\section{Complication}

Considering intraoperative complications, the most common in LTEPR is bleeding of the epigastric vessels or their collaterals in nine cases while during OPHSR only one case of epigastric artery bleeding was recorded at the time of repairing a hernia "pantaloons", in all cases bleeding control was achieved during surgery through the application of hemoclips or ligature.

Table 2. Patient's hernia classification according to Gilbert/Rutcow-Robbins criteria

\begin{tabular}{lccccccccccccc}
\hline \multicolumn{1}{c}{ OPHSR } & LTEPR & p-value \\
\hline Type & RT & $\%$ & LT & $\%$ & BIL & $\%$ & RT & $\%$ & LT & $\%$ & BIL & $\%$ & \\
\hline $\mathrm{I}$ & 0 & 0 & 1 & 0.35 & 0 & 0 & 1 & 0.34 & 0 & 0 & 5 & 1.71 & $=.057$ \\
\hline $\mathrm{II}$ & 56 & 19.71 & 39 & 13.73 & 8 & 2.82 & 8 & 2.73 & 7 & 2.39 & 74 & 25.26 & $=.216$ \\
\hline $\mathrm{III}$ & 65 & 22.88 & 43 & 15.14 & 16 & 5.63 & 6 & 2.05 & 2 & 0.68 & 50 & 17.06 & $<.001^{*}$ \\
\hline $\mathrm{IV}$ & 10 & 3.52 & 12 & 4.23 & 0 & 0 & 5 & 1.71 & 4 & 1.37 & 11 & 3.75 & $<.001^{*}$ \\
\hline $\mathrm{V}$ & 5 & 1.76 & 5 & 1.76 & 0 & 0 & 3 & 1.02 & 1 & 0.34 & 23 & 7.85 & $=.005^{*}$ \\
\hline $\mathrm{VI}$ & 6 & 2.11 & 8 & 2.82 & 0 & 0 & 2 & 0.68 & 2 & 0.68 & 48 & 16.38 & $<.001^{*}$ \\
\hline VII & 2 & 0.73 & 6 & 2.11 & 2 & 0.70 & 8 & 2.73 & 6 & 2.05 & 27 & 9.22 & $<.001^{*}$ \\
\hline *Significant differences between each type of hernia & & & & & & & &
\end{tabular}


Table 3. Additional procedures

\begin{tabular}{lcccc}
\hline PROCEDURE & \multicolumn{2}{c}{ OPHSR } & \multicolumn{2}{c}{ LTEPR } \\
\hline & N & \% & N & $\%$ \\
\hline Cholecystectomy & 0 & 0.00 & 1 & 1.37 \\
\hline Varicocele & 0 & 0.00 & 4 & 6.83 \\
\hline Umbilical hernia repair & 5 & 1.76 & 20 & 6.83 \\
\hline Epigastric hernia repair & 1 & 0.35 & 2 & 0.68 \\
\hline Hydrocele & 2 & 0.70 & 0 & 0.00 \\
\hline TOTAL & 8 & 2.82 & 27 & 9.22 \\
\hline
\end{tabular}

In the LTEPR group there was a case of bleeding from the Corona Mortis vein, and two cases of bleeding of the spermatic vessels, there was no bleeding of the iliac vessels. In the OPHSR group there was a case of bleeding of the spermatic vessels and one case of bleeding of the femoral vein during the fixation of the mesh. In all these cases, the control of bleeding was achieved in the operation without postoperative consequences.

In the LTEPR group, there was a laceration of the bladder in a patient with a recurrent hernia, suturing the bladder laparoscopically and leaving a urinary catheter for a week.

Lesion in the spermatic cord occurred in two cases of laparoscopic repair, unilaterally in patients older than 50 years, so no attempt was made to repair and hemoclips were applied only.

There were more intraoperative complications in the LTEPR group than in the OPHSR group, especially in bleeding of the epigastric vessels, which influences a significant difference $(p=.014)$.

Among postoperative complications, in both groups the presence of a hematoma stands out, without clinical significance, the presence of seroma is a more common complication in OPHSR, requiring in certain patients the evacuation by puncture and absorption. Other complications such as urinary tract infection, urinary retention, small bowel obstruction, and hydrocele occurred in both groups without significant statistical differences.

Recurrences are the most important postoperative complication since, in order to solve it, re-operation is necessary, 7 cases $(2.46 \%)$ occurred in the OPHSR group and 5 cases $(1.71 \%)$ in the LTEPR group, the difference being not significant $(p=.528)$. Postoperative complications occurred in $14.79 \%$ of patients in the OPHSR group while $10.92 \%$ in patients in the LTEPR group (Table 4).

Table 4. Intra-operative and post-operative complications

\begin{tabular}{|c|c|c|c|c|c|c|}
\hline \multirow[b]{2}{*}{ Complication } & & \multicolumn{2}{|c|}{ OPHSR } & \multicolumn{2}{|c|}{ LTEPR } & \multirow[b]{2}{*}{ p-value } \\
\hline & & $\mathbf{N}$ & Percent & $\mathbf{N}$ & Percent & \\
\hline \multicolumn{7}{|l|}{ Intra-operative } \\
\hline \multirow[t]{4}{*}{ Bleeding } & Epigastric vessels & 1 & $0.35 \%$ & 9 & $3.07 \%$ & $.013^{*}$ \\
\hline & Corona mortis & 0 & $0 \%$ & 1 & $0.34 \%$ & .326 \\
\hline & Spermatic vessels & 1 & $0.35 \%$ & 2 & $0.68 \%$ & .568 \\
\hline & Iliac vessels & 1 & $0.35 \%$ & 0 & $0 \%$ & .311 \\
\hline Urinary bladder injury & & 0 & $0 \%$ & 1 & $0.34 \%$ & .326 \\
\hline$\overline{\text { TOTAL }}$ & & 3 & $1.06 \%$ & 13 & $4.44 \%$ & $.014^{*}$ \\
\hline \multicolumn{7}{|l|}{ Post-operative } \\
\hline hematoma & & 16 & $5.63 \%$ & 18 & $6.14 \%$ & .795 \\
\hline UTI & & 1 & $0.35 \%$ & 2 & $0.68 \%$ & .581 \\
\hline Urinary retention & & 6 & $2.11 \%$ & 3 & $1.02 \%$ & .291 \\
\hline Fever & & 4 & $1.41 \%$ & 2 & $0.68 \%$ & .388 \\
\hline Infection & & 1 & $0.35 \%$ & 0 & $0 \%$ & .311 \\
\hline Small bowel obstruction & & 1 & $0.35 \%$ & 0 & $0 \%$ & .311 \\
\hline Seroma & & 6 & $2.11 \%$ & 0 & $0 \%$ & $.013^{*}$ \\
\hline Hydrocele & & 0 & $0 \%$ & 2 & $0.68 \%$ & .164 \\
\hline Recurrence & & 7 & $2.46 \%$ & 5 & $1,71 \%$ & .528 \\
\hline TOTAL & & 42 & $14.79 \%$ & 32 & $10.92 \%$ & .165 \\
\hline
\end{tabular}

UTI: Urinary tract infection. *Significant difference 


\section{Pain}

In this study, perioperative pain has been considered during the 7-day period since the surgical intervention. Postoperatively, in the OPHSR group, $77.46 \%$ of patients reported suffering from mild pain, $21.47 \%$ reported moderate pain, and $1.05 \%$ reported severe pain. While, in the LTEPR group $74.4 \%$ of patients reported mild pain, $25.25 \%$ reported moderate pain and only one patient reported severe pain, it should be noted that the post-operative pain is similar in both groups ( $\mathrm{p}=.405)$, while, all patients received nonsteroidal anti-inflammatory drug treatment only (Graph 1).
Chronically in both groups there is similarity in the persistence of pain, in a continuous way, either during efforts, work or rest or occasionally during efforts or at rest, one patient in each group reported treatment for pain continuously, 14 patients in the OPHSR group and 16 patients in the LTEPR group received painkiller medicine for periods. Paresthesia is a common complication in OPHSR (Table 5).

\section{Quality of Life}

The patients were asked about their quality of life (QoL) regarding the possibility of carrying out their normal daily activities; in the OPHSR group, 183 patients answered no

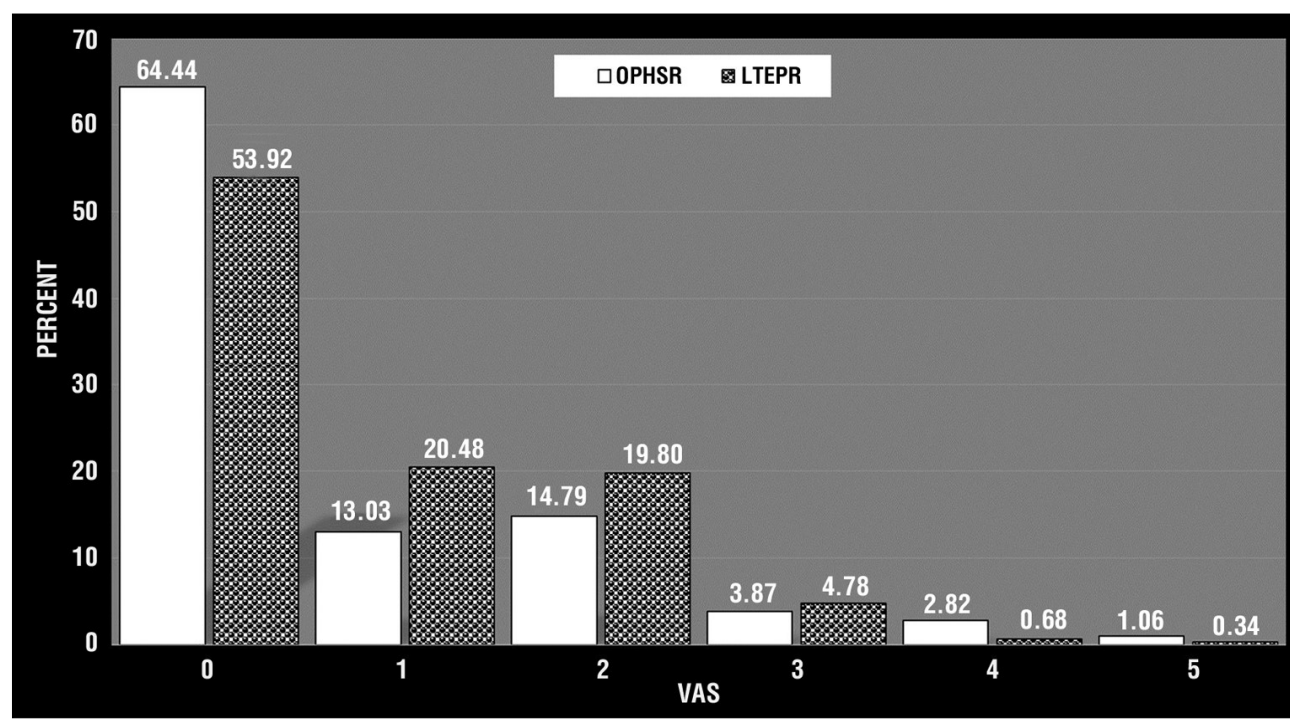

Graph 1. Perioperative pain measurein VAS from 0 to 10 points

Table 5. Postoperative chronic pain

\begin{tabular}{lccccc}
\hline & \multicolumn{2}{c}{ OPHSR } & LTEPR & p-value \\
\hline VAS (1-10) range & \multicolumn{2}{c}{0.66} & $\mathbf{N}$ & Percent & $>.999$ \\
\hline Pain characteristics & $\mathbf{N}$ & Percent & 10 & 3.52 & .585 \\
\hline Persistent pain during effort & 8 & $2.73 \%$ & 1 & $0.41 \%$ & $.660 \backslash$ \\
\hline Persistent pain at rest & 2 & $0.68 \%$ & 45 & $15.84 \%$ & .219 \\
\hline Occasional pain during effort & 36 & $12.28 \%$ & 5 & $1.76 \%$ & .806 \\
\hline Occasional pain at rest & 6 & $2.04 \%$ & 11 & $3.87 \%$ & .595 \\
\hline Occasional mild testicular pain & 14 & $4.77 \%$ & 1 & $0.35 \%$ & $<.001^{*}$ \\
\hline Paresthesia & 16 & $5.46 \%$ & 1 & $0.35 \%$ & .984 \\
\hline Permanent pain treatment & 1 & $0.34 \%$ & 16 & $5.63 \%$ & .642 \\
\hline Periodical pain treatment & 14 & $4.77 \%$ & & & \\
\hline
\end{tabular}

Vas: Visual Analog Scale, *Significant differences 
changes in their normal activity, while 83 patients improved their QoL and 12 patients responded deficiency to carry out their daily activities. In the LTEPR group, 211 patients did not experience changes in their daily activity, while 73 patients improved their daily activity after repair and nine patients responded worsening their capacity to carry out their normal activities (Graph 2). Comparing the results in the QoL of both groups does not show a significant difference $(p=.506)$.

Patients were asked to give their opinion about the scar of the operation, in the OPHSR group, $50.85 \%$ of the patients were satisfied, $29.35 \%$ were very satisfied and $19.8 \%$ were unsatisfied, in the LTEPR group, $33.45 \%$ the patients were satisfied, $64.08 \%$ very satisfied and only $2.46 \%$ were unsatisfied (Graph 3). Comparing both groups, the difference is significant in favor of the LTEPR group $(\mathrm{p}<.001)$.

About sexual function, $97.27 \%$ of the OPHSR group and $96.13 \%$ of the LTEPR group answered no change in their sexual activity, the response of both groups being similar without significant difference (Graph 4).

\section{Discussion}

This study is based on patients operated in a private practice center, this explains the fact that in our environment almost $50 \%$ of inguinal hernias have been repaired laparoscopically while it has been reported that laparoscopic repair is carried out in 15\% - $20 \%$ of patients in America (23).

The development and evolution of technology has progressed considerably in the last 20 years, in spite of this, there is no criteria that establish which is the best approach to hernias repair. We agree with Karthikesalingam in that the selection of patients and the experience of the surgeon should be the best factors that help to decide the best approach (24) as was performed in the present study. Therefore, the selection of patients who need hernia repair to offer them the best treatment leads to insoluble differences between patients in both groups.

Simultaneous procedures have been performed in both groups but in the LTEPR group, there are a greater number of cases, including the operation of the gallbladder.

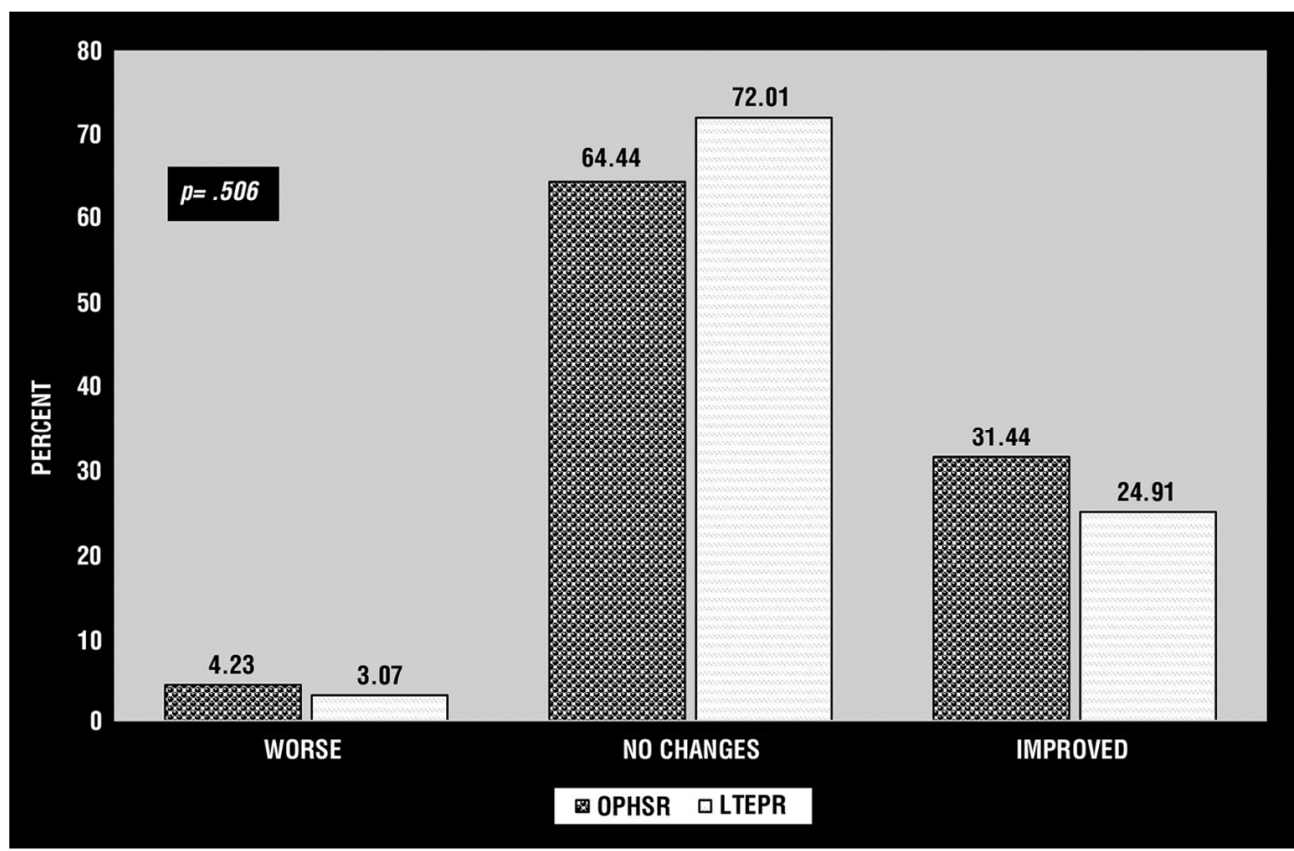

Graph 2. QOL after surgery, expressed in percent 


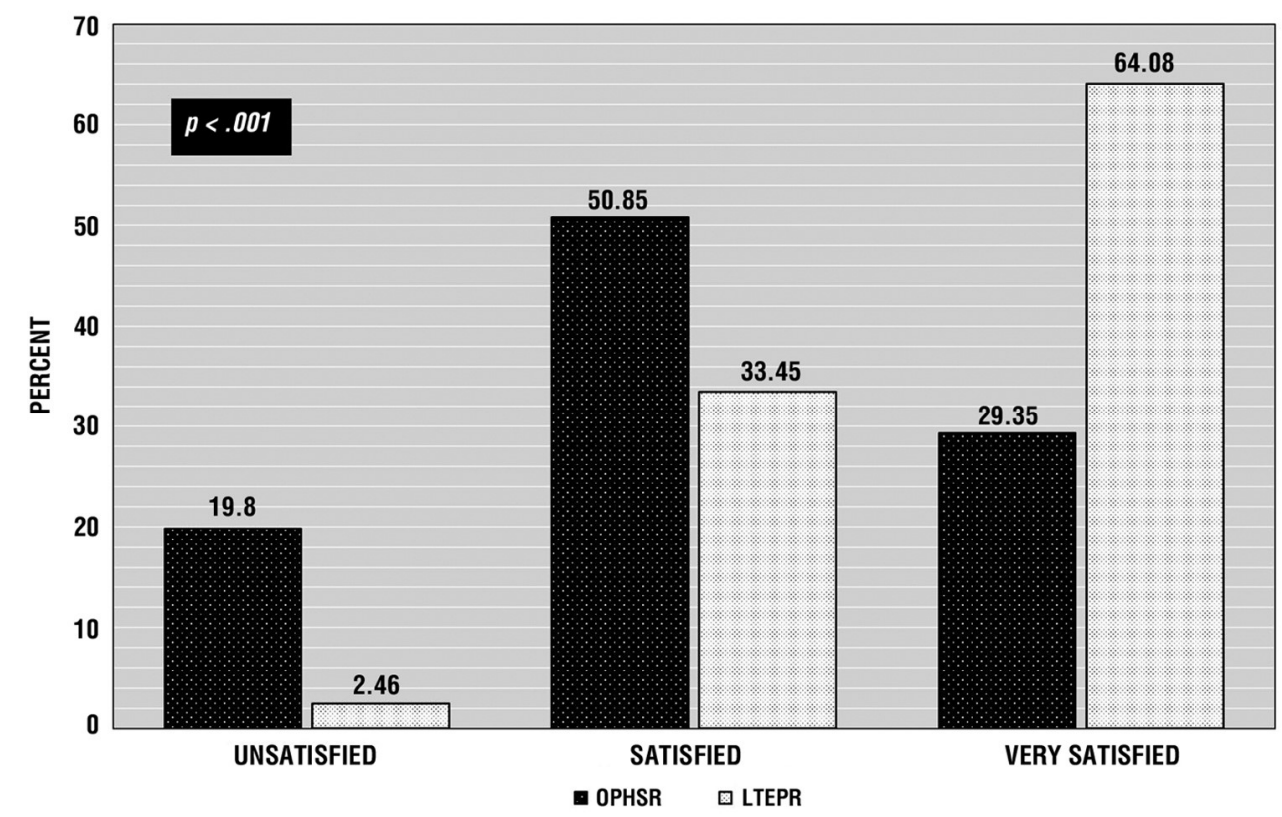

Graph 3. Surgical scar satisfaction expressed in percent of patients

According to Hayakawa, operate gallbladder and hernia at the same time is safe and can be regarded as a standard surgical procedure for patients with concomitant inguinal hernia and gallbladder stones (25).

The operative time in our results was shorter for LTEPR than for OPHSR with significant differences. In the literature, we find authors who report longer operative time for LTEPR $(26,27)$, and others who report the opposite (28), in our field the group work and the experience of the surgeon make the difference.

The most common intraoperative complica-

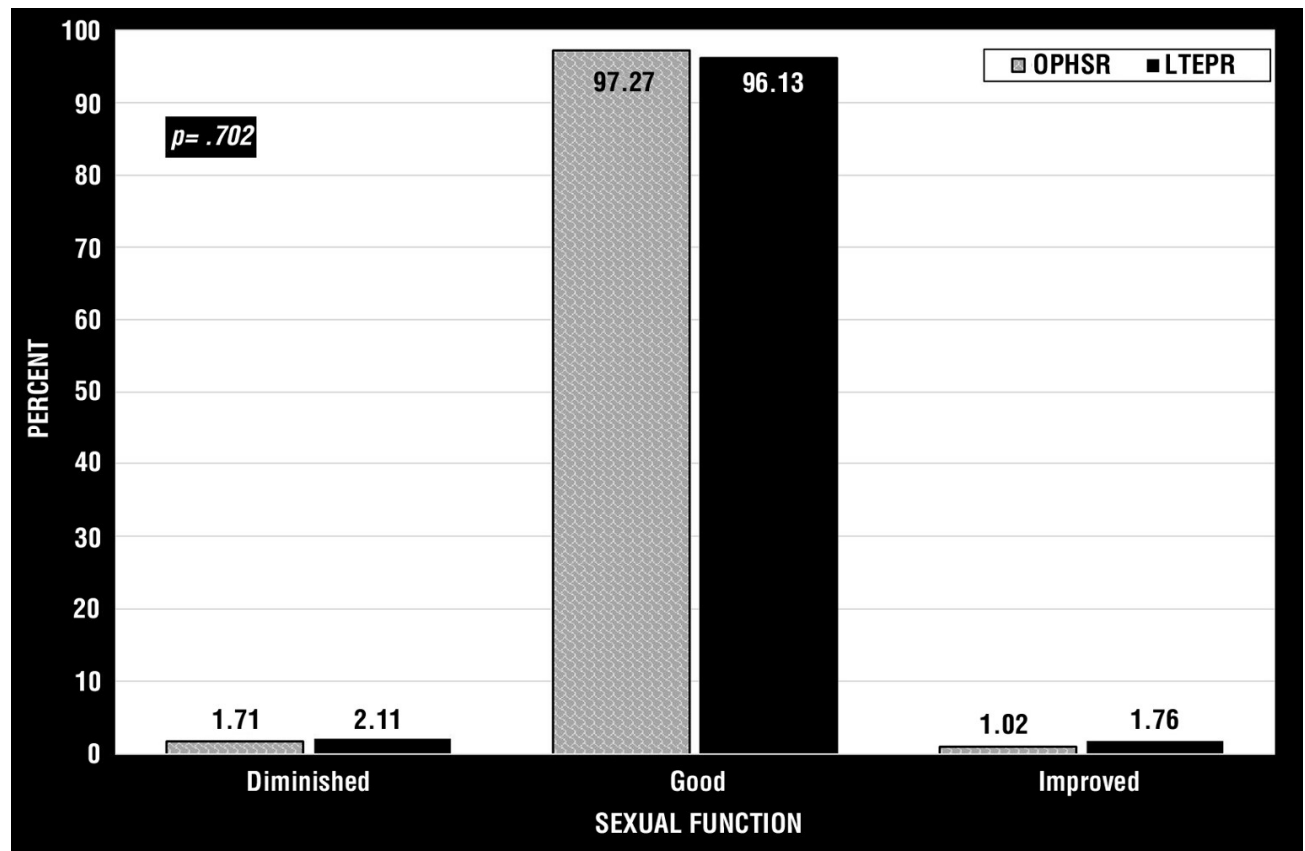

Graph 4. Sexual function after surgery expressed in percent 
tion in LTEPR was bleeding of the vessels, especially the epigastric vessels, which was resolved at the same time, in the OPHSR group there were 3 cases of intraoperative bleeding without consequences. In the LTEPR group, there was a case of bladder injury at the time of development of the preperitoneal space. The intraoperative complications are significantly greater in the LTEPR group, but without serious consequences in the postoperative period, which is in accordance with those published by Felix (29), other authors have recorded no differences (30) and other more complications in open hernia repair (31).

Bladder injury being a characteristic complication in LTEPR, occurs especially during dissection of the Retzius space and during bilateral repair in particular (32), we have noted in our patients that placing a Foley catheter in the bladder almost completely prevents this type of injuries.

Postoperative complications occurred in $14.79 \%$ in the OPHSR group and $11.60 \%$ in the LTEPR group without significant differences, the most frequent were hematomas and seromas, they were not serious and reoperations were not required. Our results coincide with that reported by Anderson in his study (33), while other authors report a higher index of postoperative complications for the laparoscopic technique (34). Although there are differences between studies when it is considered a complication to be reported.

Recurrences were $2.46 \%$ for the OPHSR group and $1.71 \%$ for the LTEPR group, without significant differences. In terms of recurrence in the literature, we found a higher reported incidence for laparoscopic repair $(31,35)$ while others reported the same incidence of retrievals comparing open or laparoscopic repair (36).

Regarding perioperative and chronic pain, we did not find significant differences in both groups; paresthesia of the upper part of the thigh is frequent in OPHSR. It has been widely reported that laparoscopic hernia repair presents much less pain than the open technique $(34,37)$. While most studies have compared Lichtenstein's repair with LTEPR, we agree with Badkur, who has compared the Lichtenstein method with OPHS repair having found that the latter technique has a positive difference in terms of moderate to intense postoperative pain, time of need for analgesics and time to return to normal activity. In the technique of LTEPR the mesh fixation should influence the degree of postoperative pain (38), from the fixation with a permanent metallic material, through the fixation with absorbable material until today with gluing fixation (39), and a self-fixating mesh is evolving to reduce the possibility of pain chronic (40). Patients with preoperative pain are more likely to suffer pain postoperatively (41)

QoL is high in both groups: $93 \%$ of patients in the OPHSR group and $96 \%$ of those in the LTEPR group did not change or improve. However, the most important thing after surgery is that in $4 \%$ of patients of the OPHSR group and $3 \%$ of those of the LTEPR repair group see a worsening in their normal daily activities. QoL is related to pain that influences activity. As Bignell states, laparoscopic surgery for inguinal hernia repair is less severe than open repair, but this does not translate into a significant improvement in QoL(42).

The mesh suture with no absorbable threads influences the QoL of the patients of the OPHSR group in a continuous way. The patients of the LTEPR group depend on a large extent on the fixation of the mesh, lately they have been reported improvement in QoL with self-fixating mesh, either open or laparoscopic approach (43).

The sexual function after hernia repair should improve if there was sexual dysfunction before, and returns to normal if there were no sexual problems before the operation according to Zieren (44). In the results of our study, we see that in more than $96 \%$ of the patients there were no changes and they returned to experience no-primate sexual activity, between one and two percent improve their sexual function, and about two percent in both groups suffer from sexual dysfunction after the operation. Sexual dysfunction is 
more common after LTEPR; Gutlic has reported that $8.2 \%$ of patients suffer from pain at the time of sexual activity and of them $6.13 \%$ suffer from dysfunction (45). Furthermore, El-Awadi has published a study in which testicular perfusion improves as well as sexual function after Lichtenstein tension-free repair (46).

Patients after LTEPR show a higher degree of satisfaction with their body and their scar than patients after OPHSR. Lamadé reports in his study that there was a significant correlation between a negative body image and the preference for scar sparing and scarless surgery indicated by a significantly increased acceptance of surgical risks and the willingness to spend additional money for receiving scarless surgery (47).

This study has the limitation of group inequality, the results obtained can be corroborated in a future randomized cohort of patients and procedure.

\section{Conclusion}

LTEPR has shorter operative time, more intraoperative complications. OPHSR and LTEPR have similar postoperative complications, recurrences, pain, and QoL. Inguinal hernia repair by open PHS or laparoscopic TEP approach has a similar outcome.

\section{Acknowledgement}

We wish to thank to Oksana Ponomarenko for her support in writing this study.

\section{Statement of Ethics}

The present study has been carried out strictly following the GCP norms, none of the authors has received any type of payment or favor for the publication. The study has been approved by the institution's ethics committee (Helsinki Committee). The consent of the patients has not been required due to the fact that it is a retrospective observational study on surgical procedures routinely used to treat the medical problem.

\section{Conflict of Interest Statement}

The authors declare no conflict of interest.

\section{Funding Sources}

For the present study, no type of financial incentive and no type of payment have been received by the institution or each of the authors.

\section{Author Contributions}

Susmallian Sergio: Conceived the study, Perform the procedures, write the manuscript. Ponomarenko Oleg: Perform the procedures, perform the data achievement, approve the manuscript. Barnea Royi: Perform the statistical analysis, manuscript supervision. All authors provided critical feedback and helped shape the research, analysis and manuscript final approvation.

\section{Ethics Approval}

This study was approved by the institution's ethics committee (Helsinki board) and has been registered in Clinical trials (NCT03842852).

\section{References}

1. Kingsnorth A, LeBlanc K. Hernias: inguinal and incisional. Lancet. 2003;362(9395):1561-71.

2. Bax T, Sheppard BC, Crass RA. Surgical options in the management of groin hernias. Am Fam Physician. 1999;59(4):893-906.

3. Rutkow IM, Robbins AW. Demographic, classificatory, and socioeconomic aspects of hernia repair in the United States. Surg Clin North Am. 1993; 73(3):413-26.

4. Primatest P, Goldacre M. Inguinal Hernia Repair: Incidence of Elective and Emergency Surgery, Readmission and Mortality. Int. J. Epidemiol. 1996; 25(4):835-839.

5. Amid P. Groin hernia repair: open techniques. World Journal of Surgery. 2005;29(8):1046-1051.

6. Beets GL, Oosterhuis KJ, Go PM, Baeten CG, Kootstra G. Longterm followup (12-15 years) of a randomized controlled trial comparing Bassini-Stetten, Shouldice, and high ligation with narrowing of the internal ring for primary inguinal hernia repair. J Am Coll Surg. 1997;185(4):352-7.

7. Kux M, Fuchsiäger N, Schemper M. Shouldice is superior to Bassini inguinalherniorrhaphy. Am J Surg. 1994;168(1):15-8.

8. Simons MP, Aufenacker T, Bay-Nielsen M, Bouillot JL, Campanelli G, Conze $J$, et al. European Hernia. Hernia Society guidelines on the treatment of inguinal hernia in adult patients. 2009;13(4):343-403.

9. Lichtenstein I, Shulman A, Amid P, Montlor M. The tension-free hernioplasty. Am J Surg. 1989;157(2):188-93 
10. Nilsson, E., Haapaniemi, S., Gruber, G. and Sandblom, G. Methods of repair and risk for reoperation in Swedish hernia surgery from 1992 to 1996. Br J Surg. 1998;85:1686-1691.

11. Simons MP, Smietanski M, Bonjer HJ, Bittner R, Miserez M, Aufenacker TJ, et al. Hernia Surge Group. International guidelines for groin hernia management. Hernia. 2018; 22(1): 1-165.

12. Wijsmuller AR, Lange JFM, Kleinrensink GJ, van Geldereetc D. Nerveidentifying inguinal hernia repair: A surgical anatomical study. World J Surg. 2007:31:414-20

13. Stoppa R, Rives J, Warlaumont C, Palo J, Verhaeghe P, Delattre J. The use of Dacron in the repair of hernias of the groin. The Surgical Clinics of North America. 1984;64 (2):269-285.

14. Nyhus LM. Laparoscopic Hernia Repair: A Point of View. Arch Surg. 1992; 127(2):137.

15. Neumayer L, Giobbie-Hurder A, Jonasson 0, Fitzgibbons R Jr, Dunlop D, Gibbs J, et al. Open mesh versus laparoscopic mesh repair of inguinal hernia. N Engl J Med. 2004;350(18):1819-27.

16. Trevisonno M, Kaneva P, Watanabe Y, Fried GM, Feldman LS, Andalib A, et al. Current practices of laparoscopic inguinal hernia repair: a populationbased analysis. Hernia. 2015;19(5):725-733.

17. Wauschkuhn CA, Schwarz J, Boekeler U, Bittner R. Laparoscopic inguinal hernia repair: gold standard in bilateral hernia repair? Results of more than 2800 patients in comparison to literature. Surg Endosc. 2010;24(12):3026-3030.

18. McCormack K, Scott NW, Go PM, Ross S, Grant AM; EU Hernia Trialists Collaboration. Laparoscopic techniques versus open techniques for inguinal hernia repair. Cochrane Database Syst Rev. 2003;(1):CD001785.

19. Gilbert A, Graham $M$, Voigt W. A bilayer patch device for inguinal hernia repair. Hernia. 1999;3(3):642-645.

20. Awad SS, Yallampalli S, Srour AM, Bellows CF, Albo D, Berger DH. Improved outcomes with the Prolene Hernia System mesh compared with the time-honored Lichtenstein onlay mesh repair for inguinal hernia repair. Am J Surg. 2007;193(6):697-701.

21. Willaert W, De Bacquer D, Rogiers X, Troisi R, Berrevoet F. Open Preperitoneal Techniques versus Lichtenstein Repair for elective Inguinal Hernias. Cochrane Database Syst Rev. 2012;(7):CD008034.

22. Campanelli G, Bruni PG, Morlacchi A, Lombardo F, Cavalli M. Primary inguinal hernia: The open repair today pros and cons. Asian J Endosc Surg. 2017;10(3):236-243

23. Davis CJ, Arregui ME. Laparoscopic repair for groin hernias. Surg Clin North Am. 2003;83(5):1141-1161.

24. Karthikesalingam A, Markar SR, Holt PJ, Praseedom RK. Meta-analysis of randomized controlled trials comparing laparoscopic with open mesh repair of recurrent inguinal hernia. Br J Surg. 201; 97(1): 4-11.

25. Hayakawa S, Hayakawa T, Inukai K, Miyai H1, Yamamoto M, Kitagami H, Shimizu Y, Tanaka M. Simultaneous transabdominal preperitoneal hernia repair and laparoscopic cholecystectomy: A report of 17 cases. Asian J Endosc Surg. 2019;12(4):396-400. Epub 2018 Nov 8.

26. McCormack K, Scott NW, Go PM, Ross S, Grant AM; EU Hernia Trialists Collaboration. Laparoscopic techniques versus open techniques for inguinal hernia repair. Cochrane Database Syst Rev. 2003;(1):CD001785.

27. Bringman S, Ramel S, Heikkinen TJ, Englund T, Westman B, Anderberg B. Tension-free inguinal hernia repair: TEP versus mesh-plug versus Lichtenstein: a prospective randomized controlled trial. Ann Surg. 2003; 237(1):142-147.

28. Winslow ER, Quasebarth M, Brunt LM. Perioperative outcomes and complications of open vs laparoscopic extraperitoneal inguinal hernia repair in a mature surgical practice. Surg Endosc. 2004;18(2):221-7.

29. Felix EL, Harbertson N, Vartanian S. Laparoscopic hernioplasty: significant complications. Surg Endosc. 1999;13(4):328-31.

30. Reiner MA, Bresnahan ER. Laparoscopic Total Extraperitoneal Hernia Repair Outcomes. JSLS. 2016;20(3). pii: e2016.00043.
31. Memon MA, Cooper NJ, Memon B, Memon MI, Abrams KR. Meta-analysis of randomized clinical trials comparing open and laparoscopic inguinal hernia repair. Br J Surg. 2003;90(12):1479-1492.

32. Köckerling F, Schug-Pass C, Adolf D, Keller T, Kuthe A. Bilateral and Unilateral Total Extraperitoneal Inguinal Hernia Repair (TEP) have Equivalent Early Outcomes: Analysis of 9395 Cases. World J Surg. 2015; 39(8):1887-94

33. Anderson B, Hallén H, Leveau P, Bergenfelz A, Westerdahl J. Laparoscopic extraperitoneal inguinal hernia repair versus open mesh repair: A prospective randomized controlled trial. Surgery. 2003;133(5):464-472.

34. Langeveld HR, van't Riet M, Weidema WF, Stassen LP, Steyerberg EW, Lange J, Bonjer HJ, Jeekel J. Total extraperitoneal inguinal hernia repair compared with Lichtenstein (the LEVEL-Trial): a randomized controlled trial. Ann Surg. 2010;251(5):819-24.

35. Eklund AS, Montgomery AK, Rasmussen IC, Sandbue RP, Bergkvist LA, Rudberg CR. Low recurrence rate after laparoscopic (TEP) and open (Lichtenstein) inguinal hernia repair: a randomized, multicenter trial with 5-year follow-up. Ann Surg. 2009;249(1):33-38.

36. Cardinali L, Hannele Mazzetti C, Cadenas Febres A, Repullo D, Bruyns J, Dapri G. Prospective randomized study comparing single-incision laparoscopic versus multi-trocar laparoscopic totally extraperitoneal (TEP) inguinal hernia repair at 2 years. Surg Endosc. 2018;32(7):3262-3272.

37. Eker HH, Langeveld HR, Klitsie PJ, van't Riet M, Stassen LP, Weidema WF, et al. Randomized clinical trial of total extraperitoneal inguinal hernioplasty vs Lichtenstein repair: a long-term follow-up study. Arch Surg. 2012; 147(3):256-60.

38. Taylor C, Layani L, Liew V, Ghusn M, Crampton N, White S. Laparoscopic inguinal hernia repair without mesh fixation, early results of a large randomized clinical trial. Surg Endosc. 2008;22(3):757-62.

39. Shi Z, Fan X, Zhai S, Zhong X, Huang D. Fibrin glue versus staple for mesh fixation in laparoscopic transabdominal preperitoneal repair of inguinal hernia: a meta-analysis and systematic review. Surg Endosc. 2017;31(2): 527-537.

40. Guerron AD, Lee HJ, Yoo J, Seymour K, Sudan R, Portenier D, et al. Laparoscopic Single-Site Inguinal Hernia Repair Using a Self-Fixating Mesh. JSLS. 2017;21(1). pii: e2016.00103

41. Hedberg HM, Hall T, Gitelis M, Lapin B, Butt Z, Linn JG, et al. Quality of life after laparoscopic totally extraperitoneal repair of an asymptomatic inguinal hernia. Surg Endosc. 2018;32(2):813-819.

42. Bignell M, Partridge G, Mahon D, Rhodes M. Prospective randomized trial of laparoscopic (transabdominal preperitoneal-TAPP) versus open (mesh) repair for bilateral and recurrent inguinal hernia: incidence of chronic groin pain and impact on quality of life: results of 10 year follow-up. Hernia. 2012;16:635-640.

43. Muysoms FE, Vanlander A, Ceulemans R, Kyle-Leinhase I, Michiels M, Jacobs I, et al. A prospective, multicenter, observational study on quality of life after laparoscopic inguinal hernia repair with ProGrip laparoscopic, self-fixating mesh according to the European Registry for Abdominal Wall Hernias Quality of Life Instrument. Surgery. 2016;160(5):1344-1357.

44. Zieren J, Menenakos C, Paul M, Müller JM. Sexual function before and after mesh repair of inguinal hernia. Int J Urol. 2005;12(1):35-38.

45. Gutlic N, Petersson U, Rogmark P, Montgomery A. The Relevance of Sexual Dysfunction Related to Groin Pain After Inguinal Hernia Repair - The SexIHQ Short Form Questionnaire Assessment. Front Surg. 2018:5:15. eCollection 2018

46. El-Awady SE, Elkholy AA. Beneficial effect of inguinal hernioplasty on testicular perfusion and sexual function. Hernia. 2009;13(3):251-258

47. Lamadé W, Friedrich C, Ulmer C, Basar T, Weiss H, Thon KP. Impact of body image on patients' attitude towards conventional, minimal invasive and natural orifice surgery. Langenbecks Arch Surg. 2011;396(3):331-336. 